\title{
Characterization of chronic HCV infection-induced apoptosis
}

\author{
Abdel-Rahman N Zekri ${ }^{*}$, Abeer A Bahnassy², Mohamed M Hafez ${ }^{1}$, Zeinab K Hassan', Mahmoud Kamel³, \\ Samah A Loutfy', Ghada M Sherif ${ }^{4}$, Abdel-Rahman El-Zayadi $^{5}$ and Sayed S Daoud ${ }^{6}$
}

\begin{abstract}
Background: To understand the complex and largely not well-understood apoptotic pathway and immune system evasion mechanisms in hepatitis C virus (HCV)-associated hepatocellular carcinoma (HCC) and HCV associated chronic hepatitis $(\mathrm{CH})$, we studied the expression patterns of a number of pro-apoptotic and anti-apoptotic genes (Fas, FasL, BCl-2, BCl-xL and Bak) in HepG2 cell line harboring HCV- genotype-4 replication. For confirmation, we also assessed the expression levels of the same group of genes in clinical samples obtained from $35 \mathrm{HCC}$ and 34 $\mathrm{CH}$ patients.
\end{abstract}

Methods: Viral replication was assessed in the tissue culture medium by RT-PCR, quantitative Real-Time PCR (qRTPCR); detection of HCV core protein by western blot and inhibition of HCV replication with siRNA. The expression level of Fas, FasL, BCl-2, BCl-xL and Bak was assessed by immunohistochemistry and RT-PCR whereas caspases 3, 8 and 9 were assessed by colorimetric assay kits up to 135 days post infection.

Results: There was a consistent increase in apoptotic activity for the first 4 weeks post-CV infection followed by a consistent decrease up to the end of the experiment. The concordance between the changes in the expression levels of Fas, FasL, Bcl-2, BCl-xL and Bak in vitro and in situ was statistically significant $(p<0.05)$. Fas was highly expressed at early stages of infection in cell lines and in normal control liver tissues followed by a dramatic reduction post-HCV infection and an increase in the expression level of FasL post HCV infection. The effect of HCV infection on other apoptotic proteins started very early post-infection, suggesting that hepatitis $C$ modulating apoptosis by modulating intracellular pro-apoptotic signals.

Conclusions: Chronic HCV infection differently modulates the apoptotic machinery during the course of infection, where the virus induces apoptosis early in the course of infection, and as the disease progresses apoptosis is modulated. This study could open a new opportunity for understanding the various signaling of apoptosis and in the developing a targeted therapy to inhibit viral persistence and HCC development.

\section{Background}

Hepatitis $\mathrm{C}$ virus (HCV) is a major worldwide causative pathogen of chronic hepatitis, cirrhosis, and hepatocellular carcinoma [1]. Egypt has the highest prevalence of $\mathrm{HCV}$ infection in the world where $15 \%$ of the total population are infected [2-4]. Although the exact mechanisms of $\mathrm{HCV}$ pathogenesis, such as viral persistence, hepatocytes injury, and hepatocarcinogenesis are not fully understood, yet an accumulating body of

\footnotetext{
* Correspondence: ncizekri@yahoo.com

'Virology and Immunology Unit, Cancer Biology Department, National

Cancer Institute, Cairo University, Egypt Full list of author information is available at the end of the article
}

evidence suggests that apoptosis of hepatocytes is significantly involved in the pathogenesis $[5,6]$.

Apoptosis plays a pivotal role in the maintenance of cellular homeostasis through removal of aged cells, damaged cells, and overgrowing new cells [7]. Failure of apoptosis induced by various stimuli is one of the most important events in tumor progression as well as in resistance to cytotoxic therapy [8]. In mammalian cells, apoptosis can be induced via two major pathways. First, the death receptor pathway (extrinsic pathway), which is triggered by binding Fas ligand (FasL) to Fas (CD95) with subsequent activation of caspase- 8 , which in turn activates the effectors caspases 3, 6, 7 [9-12]. This pathway is considered an important apoptotic system in
() Biomed Central 
cancer [13] because FasL is one of the effector molecules of cytotoxic $\mathrm{T}$ cells. The second apoptosis pathway (the intrinsic pathway) is induced by mitochondria in response to DNA damage, oxidative stress and viral proteins [5]. Mitochondria-dependent apoptosis is amplified by pro-apoptotic genes (Bax, Bad, Bak and others) whereas molecules like Bcl-2 or Bcl-xL act as anti-apoptotic. These proteins converge at the mitochondrial permeability transition pore that regulates the release of apoptotic regulatory proteins, such as procaspase- 9 , and cytochrome C [14].

There have been many studies indicating that apoptosis of hepatocytes plays a significant role in the pathogenesis of HCV infection [15], although various apoptotic pathways were proposed [16]. For example, many studies demonstrated that $\mathrm{HCV}$ core protein suppresses apoptosis mediated by cisplatin, c-myc, TNF- $\alpha$, or the Fas signaling pathway [17], whereas others showed that the core protein sensitizes Fas, TNF $\alpha$, or serum starvation-induced apoptosis [18]. The precise mechanisms for the involvement of the HCV core protein on the apoptotic pathways are not fully understood. For example, core protein-dependent inhibition of TNF- $\alpha$ and CD95 ligand-induced apoptosis has been described in a hepatoma cell line $[19,20]$. In other models, overexpressed HCV core protein did not prevent CD95 ligand induced apoptosis in hepatoma cells or transgenic mice overexpressing $\mathrm{HCV}$ core protein $[17,21]$. Until recently, the lack of an infectious HCV tissue culture system did not allow to study the impact of $\mathrm{HCV}$ infection on hepatocyte apoptosis [22].

The present study was performed to determine the changes in apoptotic machinery accompanying $\mathrm{HCV}$ infection both in vitro and in vivo. For the in vitro study, we developed a HCV replication system in HepG2 cell line, which may reflect to some extent the in vivo situation. Successful infection and propagation of the virus was assessed by detection of HCV-RNA using nested RT-PCR with specific primers, detection of increased titer by real time PCR, and virus passage to naïve cells. The HCV-HepG2 cell line was then used to study the long term effect of $\mathrm{HCV}$ infection on the apoptosis regulatory genes (Fas, FasL, Bak, Bcl-2, and Bcl-xL). This was correlated with the apoptotic activity in the cells by determining the expression levels of caspases 3, 8, and 9 . We further assessed protein expression and mRNA levels of the same group of genes in liver tissues tissue samples obtained from patients with chronic hepatitis $(\mathrm{CH})$ and hepatocellular carcinoma (HCC).

\section{Methods}

\section{Patients}

The present study included 69 cases that are HCV-RTPCR positive and HBV-PCR negative in both liver tissues and serum samples. These cases were divided into two groups: group 1 (HCC; $n=35)$, samples were collected from patients diagnosed and treated at the National Cancer Institute, Cairo University, between December 2005 and August 2008; group $2(\mathrm{CH} ; n=34)$, samples were collected from $\mathrm{HCV}$ associated chronic hepatitis $(\mathrm{CH})$ patients admitted to Kasr Al-Aini School of Medicine, Cairo University, in the same period and enrolled in routine diagnosis or therapeutic procedures. The mean age of $\mathrm{CH}$ patients was 47.5 years and M:F ratio was 1.5:1, whereas the mean age of HCC was 51.6 years and M:F ratio was 1.3:1.

All cases of $\mathrm{CH}$ were graded and staged according to the modified Knodell scoring system [23] and all HCC cases were graded according to the World Health Organization (WHO) classification criteria and staged according to the American Joint Committee on Cancer [24]. The percent of normal to tumor ratio were more than $80 \%$ in all studied cases to overcome the nominalization effect of the tumor stroma and/or necrosis as well as the cirrhotic tissues factors in the studied specimens. Table 1 illustrates the clinico-pathological features of the studied cases. Normal liver tissue samples were obtained from liver transplant donors (15 samples) and were used as controls. A written consent was obtained from all patients and normal liver donors prior to enrollment in the study and the ethical committee of

Table 1 Clinical features of the studied groups of patients.

\begin{tabular}{|c|c|c|}
\hline \multirow[t]{2}{*}{ Variables } & $\mathrm{HCC}$ & $\mathrm{CH}$ \\
\hline & $n=35(\%)$ & $n=34(\%)$ \\
\hline \multicolumn{3}{|c|}{ Liver Function Test (Mean \pm SD) } \\
\hline ALT & $77.2 \pm 76.2$ & $74.33 \pm 30.97$ \\
\hline AST & $70.577 \pm 49.4$ & $81.66 \pm 35.35$ \\
\hline Alk ph & $181.1 \pm 174.2$ & $111.57 \pm 61.58$ \\
\hline Alb & $3.758 \pm 0.707$ & $3.9 \pm 0.538$ \\
\hline T.Bil & $1.1846 \pm 0.523$ & $1.34 \pm 0.897$ \\
\hline INR & $1.179 \pm 0.067$ & $1.22 \pm 0.161$ \\
\hline \multicolumn{3}{|c|}{ Complete Blood Picture (Mean \pm SD) } \\
\hline $\mathrm{Hb}$ & $12.3 \pm 1.64$ & $13.59 \pm 2.24$ \\
\hline TLC & $6.186 \pm 3.163$ & $6.509 \pm 2.05$ \\
\hline Plt & $177 \pm 121$ & $175.5 \pm 67.267$ \\
\hline \multicolumn{3}{|l|}{ Viral marker } \\
\hline HBs-Ag & $0(0)$ & $0(0)$ \\
\hline $\mathrm{HCV}-\mathrm{Ab}$ & $35(100)$ & $34(100)$ \\
\hline HBV-PCR & $0(0)$ & $0(0)$ \\
\hline HCV-PCR & $35(100)$ & $34(100)$ \\
\hline \multicolumn{3}{|c|}{ Tumor Marker (Mean \pm SD) } \\
\hline Serum AFP & $1885 \pm 5888$ & $265 \pm 110$ \\
\hline \multicolumn{3}{|c|}{$\begin{array}{l}\text { AFP, alpha fetoprotein; Alb, albumin; Alk, Alkaline Phosphates; ALT, alanine } \\
\text { aminotransferase; } \mathrm{CH} \text {, chronic hepatitis; Hb, hemoglobin; HBs-Ag, hepatitis B } \\
\text { surface antigen; HCC, hepatocellular carcinoma; HCV, hepatitis C virus; INR, } \\
\text { International normalized ratio; PCR, polymerase chain reaction; Plt, platelet } \\
\text { count; TLC, total leukocytic count; T.Bil, total bilirubin. }\end{array}$} \\
\hline
\end{tabular}


NCI approved the protocol, which was in accordance with the ethical guidelines of the 1975 Declaration of Helsinki.

\section{HepG2 cell culture}

HepG2 cells were used to establish the in vitro $\mathrm{HCV}$ replication. HepG2 culturing and infection were carried out according to previous protocols [25]. Briefly, HepG2 cells were maintained in $75 \mathrm{~cm}$ culture flasks (Greiner bio-one GmbH, Germany) containing Dulbecco's Modified Eagle's Medium (DMEM) supplemented with $4.5 \mathrm{~g} /$ L glucose and $10 \mathrm{~g} / \mathrm{L}$ L-glutamine (Bio Whittaker, a Combrex Company, Belgium), $50 \mathrm{ml} / \mathrm{L}$ fetal calf serum (FCS), $10 \mathrm{~g} / \mathrm{L}$ penicillin/streptomycin and $1 \mathrm{~g} / \mathrm{L}$ fungizone $(250 \mathrm{mg} / \mathrm{L}$, Gibco-BRL life Technologies, Grand Island, NY (USA). The complete culture medium (CCM) was renewed every 3 days, and cells were passaged every 6-10 days. A total of $3 \times 10^{6}$ cells were suspended in $10 \mathrm{ml} \mathrm{CCM}$ and incubated at $37^{\circ} \mathrm{C}$ in $5 \%$ $\mathrm{CO}_{2}$.

\section{Viral inoculation and sample collection}

Viral inoculation and cell culture were performed as previously described [26]. Briefly, cells were grown for $48 \mathrm{~h}$ to semi-confluence in complete culture medium, washed twice with FCS-free medium, and then inoculated with $500 \mu \mathrm{l}$ serum obtained from HCV infected patients $(500 \mu \mathrm{l}$ patient sera and $500 \mu \mathrm{l}$ FCS-free $\mathrm{DMEM} / 3 \times 10^{6}$ cells). The HCV genotype was characterized as genotype- 4 with 9 quasispecies based on our previously described method [27]. The viral load in the used serum was quantified by real time PCR. The average copy number was $58 \times 10^{7}$ copies $/ \mathrm{ml}$. After $180 \mathrm{~min}$, Ham F12 medium (Bio Whittaker, a Combrex Company, Belgium) containing FCS was added to make the overall serum content $100 \mathrm{ml} / \mathrm{L}$ in a final volume of 10 $\mathrm{ml}$ including the volume of the human serum, which used for infection as mentioned above. Cells were maintained overnight at $37^{\circ} \mathrm{C}$ in $5 \% \mathrm{CO}_{2}$. The next day, adherent cells were washed with CCM and incubation was continued in CCM with $100 \mathrm{ml} / \mathrm{L}$ FCS. Throughout the culture duration, the assessment of $\mathrm{HCV}$ replication were confirmed by a detection of viral core protein using western blotting, by RT-PCR amplification of sense and antisense strands of the virus by real time PCR and by the inhibition of HCV replication using siRNA knockout as we previously reported [28].

\section{Western blot analysis of HCV core antigens in HepG2 cells}

Lysates containing $100 \mu \mathrm{g}$ of protein from uninfected and infected HepG2 cells were subjected to SDS-PAGE, as previously described [26,27]. After three washes, membranes were incubated with diluted peroxidase- labeled anti-human IgG/IgM antibody mixture at 1:5000 in PBS (3 g/L) for previously treated strips with the anti-core antibody (Novocastra, Novocastra Laboratories, UK) for $2 \mathrm{~h}$ at room temperature. Visualization of immune complexes on the nitrocellulose membranes was performed by developing the strips with $0.01 \mathrm{~mol} / \mathrm{L}$ PBS (pH 7.4) containing $40 \mathrm{mg} 3,3$ ',5,5'-tretramethylbenzidine and $100 \mu \mathrm{l}$ of $30 \mathrm{ml} / \mathrm{L}$ hydrogen peroxide (Immunopure TMB substrate Kit, PIERCE, Rockford, IIIinois, USA).

\section{Quantification of human GAPDH mRNA}

The integrity of the cellular RNA preparations from HCV infected HepG2 cells was analyzed by $18 \mathrm{~s}$ and $28 \mathrm{~s}$ bands on agarose gel and by automated gel electrophoresis (Experion Software Version 3.0, Bio-Rad), which was also used for measuring the RNA concentration in addition to spectrophotometer at $260 \mathrm{~nm}$ (nanoDrop, USA). GAPDH mRNA levels were quantified by real time RT-PCR using TaqMan technology with GAPDH specific primers. Amplification of human GAPDH transcripts was performed using the TaqMan EZ RT-PCR kit (Applied Biosystems, Foster City, CA). The target template was the purified cellular RNA from HepG2 cells at $1,2,3,4,5,6,7$ and 8 days post-infection with $\mathrm{HCV}$, in absence and presence of siRNA. The RT-PCR was performed using a single-tube, single-enzyme system. The reaction exploits the 5'-nuclease activity of the rTth DNA polymerase to cleave a TaqMan fluorogenic probe that anneals to the cDNA during PCR $50 \mu \mathrm{l}$ reaction volume, $1.5 \mu \mathrm{l}$ of RNA template solution equivalent to total cellular RNA from $2.5 \times 10^{5}$ cells were mixed with $200 \mathrm{nM}$ forward primer, $200 \mathrm{nM}$ reverse primer, $300 \mathrm{nM}$ GAPDH probe, $300 \mu \mathrm{M}$ from each of dATP, dCTP, dGTP and $600 \mu \mathrm{M}$ dUTP, $3 \mathrm{mM}$ manganese acetate, $0.5 \mu \mathrm{l}$ rTth DNA polymerase, $0.5 \mu \mathrm{l}$ Amp Erase UNG, $1 \times$ Taqman EZ buffer and amplified in the sequence detection system ABI 7700 (Applied Biosystems, Foster City, CA). The RT-PCR thermal protocol was as follows: Initial UNG treatment at $50^{\circ} \mathrm{C}$ for 2 minutes, RT at $60^{\circ} \mathrm{C}$ for 30 minutes, deactivation of UNG at $95^{\circ} \mathrm{C}$ for 5 minutes followed by 40 cycles, each of which consists of denaturation at $94^{\circ} \mathrm{C}$ for 20 seconds and annealing/extension at $62^{\circ} \mathrm{C}$ for $1 \mathrm{~min}$.

\section{Northern Blot Analysis}

To construct a HCV RNA transcription vector total RNA was extracted from all cell types at days 1, 2, 3, 4, 5, 6, 7 and 8 post-transfection, $5 \mu \mathrm{g}$ of total RNA were loaded onto the gel. HCV sequences from nt 47 to 1032 were cloned after RT-PCR into pSP 64 [poly(A)] vector (Promega), resulting in plasmid PMOZ.1.HCV then confirmed by DNA sequence analysis. HCV template RNA was transcribed in vitro from MOZ.1.HCV. Briefly, $5 \mathrm{mg}$ 
of plasmid DNA was linearized with a BglII. The linear plasmid DNA was purified from an agarose gel and then incubated with $50 \mathrm{U}$ of SP6 RNA polymerase for $2 \mathrm{~h}$ at $37^{\circ} \mathrm{C}$ in the presence of $500 \mathrm{mM}$ (each) ribonucleoside triphosphates (GTP, ATP, UTP, and CTP), $100 \mathrm{U}$ of RNAsin, $10 \mathrm{mM}$ dithiothreitol, $40 \mathrm{mM}$ Tris- $\mathrm{HCl}(\mathrm{pH}$ 7.5), $6 \mathrm{mM} \mathrm{MgCl} 2,2 \mathrm{mM}$ spermidine, and $10 \mathrm{mM}$ $\mathrm{NaCl}$ in a total reaction volume of $100 \mu \mathrm{l}$. After transcription reaction, DNA template was degraded by two rounds of digestion with RNase-free DNase (Boehringer) for $30 \mathrm{~min}$ at $37^{\circ} \mathrm{C}$ with $10 \mathrm{U}$ of enzyme. Upon completion of digestion, two rounds of extraction with phenolchloroform-isopropyl alcohol and then ethanol precipitation were done. HCV RNA transcripts, which contained a poly(A) tail, were further purified on an oligo (dT) cellulose column. RNA concentration was determined spectrophotometrically at A260 with UV light. An aliquot was analyzed by agarose gel electrophoresis to assess its integrity.

\section{Sensitivity of RT-PCR assay}

HCV RNA synthesized in vitro was diluted with TE (Tris-EDTA) buffer at a concentration of approximately 106 copies per $\mathrm{ml}$ and was stored at $-20^{\circ} \mathrm{C}$. Serial $10-$ fold dilutions of these stock solutions were made in water just prior to RT-PCRs. One hundred copies were routinely detected. Both probes were purified using MicroSpin G-50 columns (Amersham Pharmacia). Blots were visualized and quantified as previously described [29].

\section{Detection of plus and minus-strand RNA by nested RT- PCR}

Detection of plus- and minus- HCV strand was performed as previously reported $[26,30]$. The One Step real-time PCR system (Applied Biosystems) was used.

\section{Molecular detection of HBV}

DNA extraction and PCR amplification from fresh tissues and PCR amplification were performed as previously described [31].

\section{Determination of caspase activity}

HepG2 cells were harvested on different dates. After lysis and protein concentration, cell lysates containing $200 \mu \mathrm{g}$ of total protein was used to measure the activities of caspases 3, 8 and 9 using ApoTaget colorimetric Assay kits (BioSource international, Inc. Camarillo, CA) according to the manufacturer instructions.

\section{RNA extraction from liver tissues}

Total RNAs were extracted using a SV total RNA isolation system (Promega, Biotech) according to manufacturer's instructions. The extracted total RNA was assessed for degradation, purity and DNA contamination by a spectrophotometer and electrophoresis in an ethidium bromide-stained 1.0\% agarose gel. Ten samples of normal human DNA and RNA were extracted from normal liver tissues and were used to optimize the best conditions for the multiplex PCR of B-actin gene (621bp fragments) versus each of the studied genes. Negative RT-PCR control was used against each sample [32].

\section{c-DNA synthesis}

Reverse transcription (RT) of the isolated total RNA was performed in $25 \mu$ l reaction volume containing $200 \mathrm{u}$ of Superscript II RT enzyme (Gibco-BRL, Gaithersburg, MD, USA.), $1 \times$ RT-buffer [250 mM Tris- $\mathrm{HCl} \mathrm{pH} 8.3$, $375 \mathrm{mM} \mathrm{KCl}, 15 \mathrm{mM} \mathrm{MgCl} 2$ ], $1 \mathrm{mM}$ dithiotheritol, 25 ng from random primer, $0.6 \mathrm{mM}$ deoxynucleotide triphosphates, $20 \mathrm{U}$ RNAsin (Promega, USA.), $100 \mathrm{ng}$ of extracted RNA. Samples were then incubated at $50^{\circ} \mathrm{C}$ for $60 \mathrm{~min}$ followed by $4^{\circ} \mathrm{C}$ until the PCR amplification reaction [32].

\section{PCR amplification of the studied genes}

Primer sequences, PCR conditions of the studied genes (Fas, FasL, Bcl-2, Bcl-xL and Bak), and the expected PCR DNA band length are listed in Table 2. The PCR and quantitation were performed in a $50 \mu \mathrm{L}$ reaction volume containing $5 \mu \mathrm{L}$ of the $\mathrm{RT}$ reaction mixture (cDNA), 2.5 units Taq polymerase (Gibco-BRL, Gaithersburg, MD, USA), 1× PCR buffer (500 mM KCl, $200 \mathrm{mM}$ Tris- $\mathrm{HCl}, 1.5 \mathrm{mM} \mathrm{MgCl}$, $1 \mathrm{mg} / \mathrm{mL}$ bovine serum albumin (BSA)), $200 \mathrm{mM}$ each of the deoxyribonucleotide triphosphate and $0.25 \mathrm{mM}$ of each primer. Amplification of the $\beta$-actin gene (621 bp fragment) was performed to test for the presence of artifacts and to assess the quality of RNA. A water control tube containing all reagents except c-DNA was also included in each batch of PCR assays to monitor contamination of genomic DNA in the PCR reagents. Negative RT-PCR control was used against each sample [32].

Table 2 Primer sequences of the studied genes.

\begin{tabular}{lll}
\hline $\begin{array}{l}\text { Gene } \\
\text { Name }\end{array}$ & Primer Sequence & \multicolumn{1}{l}{$\begin{array}{l}\text { Fragment } \\
\text { Length }\end{array}$} \\
\hline $\boldsymbol{\beta}$-actin & 5'-ACA CTG TGC CCA ACG AGG-3' & $621 \mathrm{bp}$ \\
& 5'-AGG GGC CGG TCA T AC T-3 & \\
Fas & 5'-GCAACACCAAGTGCAAAGAGG-3' & $265 \mathrm{bp}$ \\
& 5'-GTCACTAGTAATGTCCTTGAGG-3' & \\
FasL & 5'-ATGTTCAGCTCTTCCACCTACAGA-3' & $255 \mathrm{bp}$ \\
& 5'-CCAGAGAGAGCTCAGATACGTGAC-3' & \\
Bak & 5'-TGATACCTGTGCTTATCCC -3' & $250 \mathrm{bp}$ \\
& 5'-AAACCAGCATCTCTCTAAAC-3' & \\
Bcl-2 & 5' GCAGATCCAGGTGATTCTCG 3' & $234 \mathrm{bp}$ \\
& 5' ATCGATGCCAATGACAGCCA 3' & \\
Bcl-XL & 5'-CCCGGTGCTGCAGCATGTCCT -3' & $521 \mathrm{bp}$ \\
& 5'-TCCCCTCGAGGATTCGACAG -3' & \\
\hline
\end{tabular}




\section{Quantification of the studied genes}

Fifteen microliters of each PCR product were separated by electrophoresis through a $2.0 \%$ ethidium bromidestained agarose gel and visualized with ultraviolet light. Gels were photographed and the bands were scanned as digital peaks. Areas of the peaks were then calculated in arbitrary units with a digital imaging system (Photo-documentation system, Model IS-1000; Alpha Innotech Co., San Leandro, CA, USA). To evaluate the relative expression levels of target genes in the RT-PCR, the expression value of the normal pooled liver tissues was used as a normalizing factor and a relative value was calculated for each target gene amplified in the reaction. Nonexpression in any of the studied genes was considered if there was a complete absence, or more than a $75 \%$ decrease in the intensity of the desired band in comparison to the band of normal pooled liver tissue [24,25]. Samples were assayed in batches that included both cases and controls. The absence of bands was confirmed by repeating the RT-PCR twice at different days and by consistent presence of $\beta$-actin gene amplification [32].

\section{Immunohistochemistry}

Protein expression of the studied proteins was assessed using the following monoclonal antibodies Fas (C236), FasL (sc-56103), Bcl-2 (sc-56016), and Bcl-xL (sc-8392) (all from Santa Cruz Biotechnology, inc. Germany). Briefly, from each tumor block, a hematoxylin and eosinstained slide was microscopically examined to confirm the diagnosis and select representative tumor areas. Tissue cores with a diameter of $1.5 \mathrm{~mm}$ were punched from the original block and arrayed in triplicate on 2 recipient paraffin blocks. Five $\mu \mathrm{m}$ sections of these tissue array blocks were cut and placed on positive charged slides to be used for IHC analysis. Sections from tissue microarrays were deparaffinized, re-hydrated through a series of graded alcohols, and processed using the avidin-biotin immunoperoxidase methods. Diamino-benzidine was used as a chromogen and Mayer hematoxylin as a nuclear counterstain. A case of follicular lymphoma was used as a positive control for Bcl-2, Fas and FasL whereas a case of colon cancer was used as a control for Bcl-xL. Results were scored by estimating the percentage of tumor cells showing characteristic cytoplasmic immunostaining for all examined markers [33].

Protein expression was classified compared to normal hepatic tissue samples. Positive expression was further classified according to the level of expression into mild: $\geq 10 \%-<25 \%$, moderate: $\geq 25 \%-<50 \%$ and high expression: $\geq 50 \%$ but during statistical analysis they were broadly classified into negative or positive expression.

\section{Statistical analysis}

The results were analyzed using the Graph Pad Prism software (Graph Pad Software, San Diego, CA, USA). For gene expression analysis the Mann-Whitney U Test was used for numeric variables and Chi square or Fisher's exact Test were used to analyze categorical variables. $P$-value was considered significant when $\leq 0.05$.

\section{Results}

All studied cases were positive for $\mathrm{HCV}$ infection by both ELISA and HCV RT-PCR in serum and liver tissue but were negative for HBV infection by serological markers and PCR both in serum and liver tissues. The level of pro-apoptotic genes expression was measured in HCV infected HepG2 cell line as an in vitro model as well as in $\mathrm{HCC}$ and $\mathrm{CH}$ tissue samples.

\section{Infection of HepG2 cell line with hepatitis $C$ virus}

In this model, we observed a good correlation between persistence of $\mathrm{HCV}$ infection in HepG2 cell line and the appearance of certain morphological changes in the infected cells such as visible cell aggregation and granulation that took place 21 days post infection suggesting successful viral transfection, as shown in Figure 1. Successful HCV genotype-4 replication in HepG2 cells were also confirmed by western blot for the detection of viral core protein as shown in Figure 2a, as well as inhibition of $\mathrm{HCV}$ replication by $100 \mathrm{nM}$ siRNA previously developed in our lab [28], illustrated in Figure 2b.

Quantification of HCV RNA was performed both in cell free media and cell lysates at days 1, 2, 3, 7, 14, 21, $28,35,42,52,59$ and 116 post $\mathrm{HCV}$ infection. HCV RNA was detected in all of these days except days 35 , 52 for cell free media and days 21, 28 for cell lysates. HCV-RNA was quantitatively detected in all days except days $2,3,14,45$ (Table 3 ).

\section{Apoptotic genes expression in HCV-infected HepG2 cells}

No changes in the expression level of Bcl-2 gene post$\mathrm{HCV}$ infection was observed compared to the control (HCV free HepG2 cells) (Figure 3A). The expression of $\mathrm{Bcl}-\mathrm{xL}$ and Bak genes (Figures 3B, C, respectively) fluctuated 3 weeks post infection then, the levels of their expression was similar to the control levels at the end of the experiment. Interestingly, there was a good correlation between Fas, FasL genes expression and HCV infection. The expression of Fas gene was visible until the third measurement (day 3) post infection and then disappeared by the end of the experiment. In contrast, the expression of FasL was not visible until day 21 post infection then the visibility progressively increased until the end of the experiment (Table 3 Figures 3D, E). 

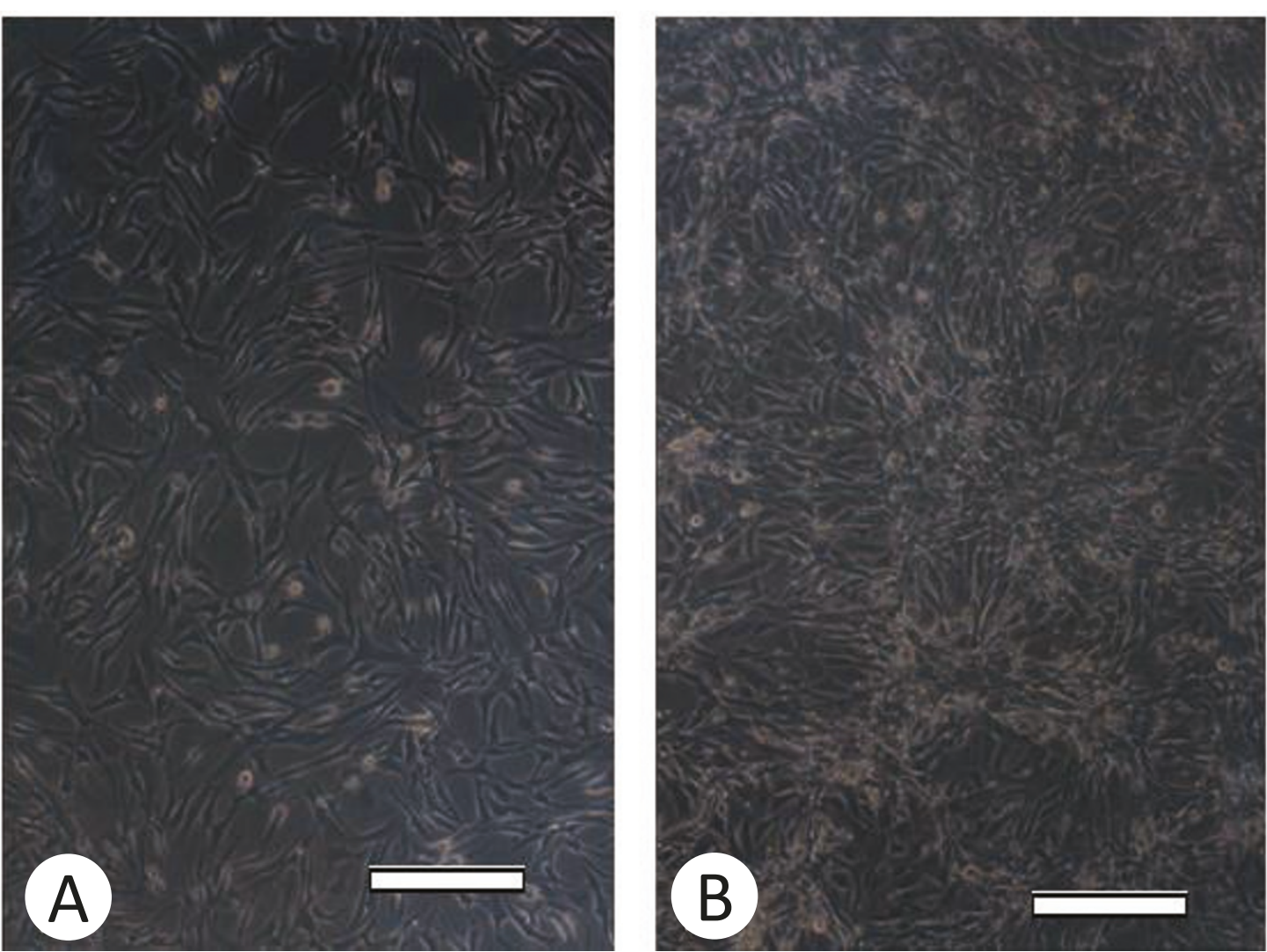

Figure 1 (A): Non-infected HePG2 cells. (B): Infected HePG2 cells. Scale bar = $100 \mu \mathrm{m}$.

\section{Caspases activity in HCV-infected HepG2 cells}

As shown in Figure 4, recognizable changes were observed in caspases 3, 8 and 9 throughout the course of HCV infection. There was an initial increase in their levels starting from day six to day 30 then all caspases levels were dramatically decreased until day 135 postinfection.

\section{Apoptotic genes expression in the studied cohorts of patients}

There was a significant difference in the RNA expression level of both $\mathrm{Bcl}-\mathrm{xL}$ and $\mathrm{Bcl}-2$ genes between $\mathrm{HCC}$ and $\mathrm{CH}(26 \%, 80 \%$ versus $0 \%, 59 \%$; respectively, $\mathrm{p}<$ $0.0001,=0.0068)$. As well as between HCC cases and normal distant tumor (NDT) ( $<0.001$ ) (Figure 5). Similarly, a significant difference was found in the Bak gene expression between $\mathrm{HCC}$ and $\mathrm{CH}$ patients (69\% versus $47 \%, \mathrm{p}=0.0025$ ) as well as between $\mathrm{HCC}$ and NDT $(\mathrm{p}<0.0001)$. The FasL was significantly expressed in $\mathrm{CH}$ compared to $\mathrm{HCC}(47 \%$ versus $23 \%$, $\mathrm{p}<0.001)$. None of the $\mathrm{CH}$ cases studied revealed $\mathrm{Bcl}-\mathrm{xL}$ gene expression.

\section{Apoptotic proteins expression}

Positive immunostaining for Bcl-2, Bcl-xL, Fas and FasL proteins was detected in 29 (85.9\%), 12 (34.3\%), $21(60 \%)$ and $9(25.7 \%)$ the studied samples of the 35 HCC cases examined compared to 18 (52.9\%), 0 (0\%), $18(52.9 \%)$ and $18(52.9 \%)$ of samples of the $34 \mathrm{CH}$ cases; respectively. The concordance between immunohistochemistry and RT-PCR ranged from $86 \%$ to $94 \%$ (Figure 6).

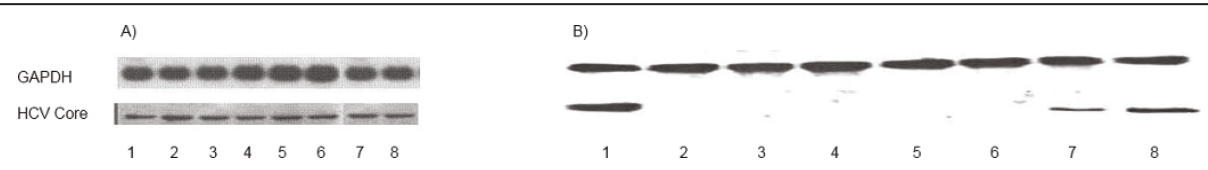

Figure 2 Expression levels of the viral core and GAPDH. (A) The expression level of the viral core and GAPDH in HepG2 cells infected by HCV genotype-4 from day 1 to day 8. (B) The expression level of the viral core in HepG-2 cells infected by HCV genotype-4 from day 1 to day 8. Upper row show HCV-core expression in un-transfected cells. Lower row showed the HCV-core expression in siRNA-Z5 transfected cells. 
Table 3 Changes in apoptotic and pre apoptotic genes expression in HCV infected HepG2 cell line in vitro.

\begin{tabular}{|c|c|c|c|c|c|c|c|}
\hline & Qualitative/Quantitative PCR (copy number/ml) & & Apopt & gene & & & \\
\hline Days & Cell free media & Cell lysate & $\mathrm{Bcl}-\mathrm{xL}$ & $\mathrm{Bcl}-2$ & Bak & Fas & FasL \\
\hline$\overline{\text { Day1 }}$ & Positive/785 & Positive & - & + & +++ & ++ & - \\
\hline Day2 & Positive/Negative & Positive & - & + & + & ++ & - \\
\hline Day3 & Negative/Negative & Positive & - & + & ++ & ++ & - \\
\hline Day7 & Positive/13005 & Positive & - & + & + & - & - \\
\hline Day 14 & Positive/Negative & Positive & - & + & + & - & - \\
\hline Day21 & Negative/6782 & Positive & - & + & - & - & + \\
\hline Day28 & Negative/24678 & Positive & + & + & ++ & - & + \\
\hline Day35 & Positive/8892 & Negative & - & + & - & - & + \\
\hline Day45 & Positive/Negative & Positive & + & + & - & - & ++ \\
\hline Day52 & Positive/7374 & Negative & - & + & - & - & +++ \\
\hline Day59 & Positive/22963 & Positive & + & + & ++ & - & +++ \\
\hline HepG2 Control & - & - & - & + & + & + & - \\
\hline
\end{tabular}

+: Equal to the expression level in the HepG2; ++: twofold increase in the expression level; +++ threefold increase in the expression level.



Figure 3 Data on gene amplification. Ethidium bromide-stained 2\% agarose gel (A) for BCl2 gene amplification. Lanes 1 and 2 showed negative RT-PCR control; lane 3 showed positive amplification of $\mathrm{CH}$ case; lane 4 showed negative amplification of $\mathrm{CH}$ case; lane 5 showed positive amplification of HCC case; lane 6 showed negative amplification of HCC case; lane 7 showed positive amplification of HepG2 without HCV infection; lane 8 showed positive amplification of HepG2 with HCV infection. (B) For BCl-XI gene amplification. Lane 1 showed HepG2positive amplification with HCV infection at day 28; lane 2 HepG2-negative amplification without HCV infection; lane 3 and 4 showed positive amplification of $\mathrm{CH}$ case; lane 5 showed positive amplification of HCC case; lane 6 \& 7 showed negative RT-PCR control. (C) For Bak gene amplification. lane 1 HepG2-positive amplification with HCV infection at days 59; lane 2 HepG2-negative amplification without HCV infection lane 3 showed HepG2-negative amplification with HCV infection at days 35; lane 4 showed positive amplification of CH case; lane 5 showed positive amplification of HCC case of CH; lane 6 negative RT-PCR control. (D) for Fas gene amplification, first lane: MW, lanes 1 and 2: negative RT-PCR control, lane 3 showed HepG2-positive amplification without HCV infection, lane 4 HepG2- showed negative amplification with HCV infection at day 21, lane 5 showed negative case of HCC, lanes 6 and 7 showed positive amplification of CH and lane 8 showed positive amplification of HCC case. (E) for FasL gene amplification, lane 1: negative RT-PCR control; lanes 2 and 3 showed HepG2-positive amplification with HCV infection at days 28 and 35 respectively; lane 4 showed HepG2-negative amplification without HCV infection; lane 5 showed negative case of CH; lanes 6 and 7 showed positive amplification of $\mathrm{CH}$, lanes 8 and 9 showed positive amplification of HCC case. (F) Amplification plot of RT-PCR for housekeeping gene using Taqman probe. 
Zekri et al. Comparative Hepatology 2011, 10:4

Page 8 of 14

http://www.comparative-hepatology.com/content/10/1/4

A)



B)

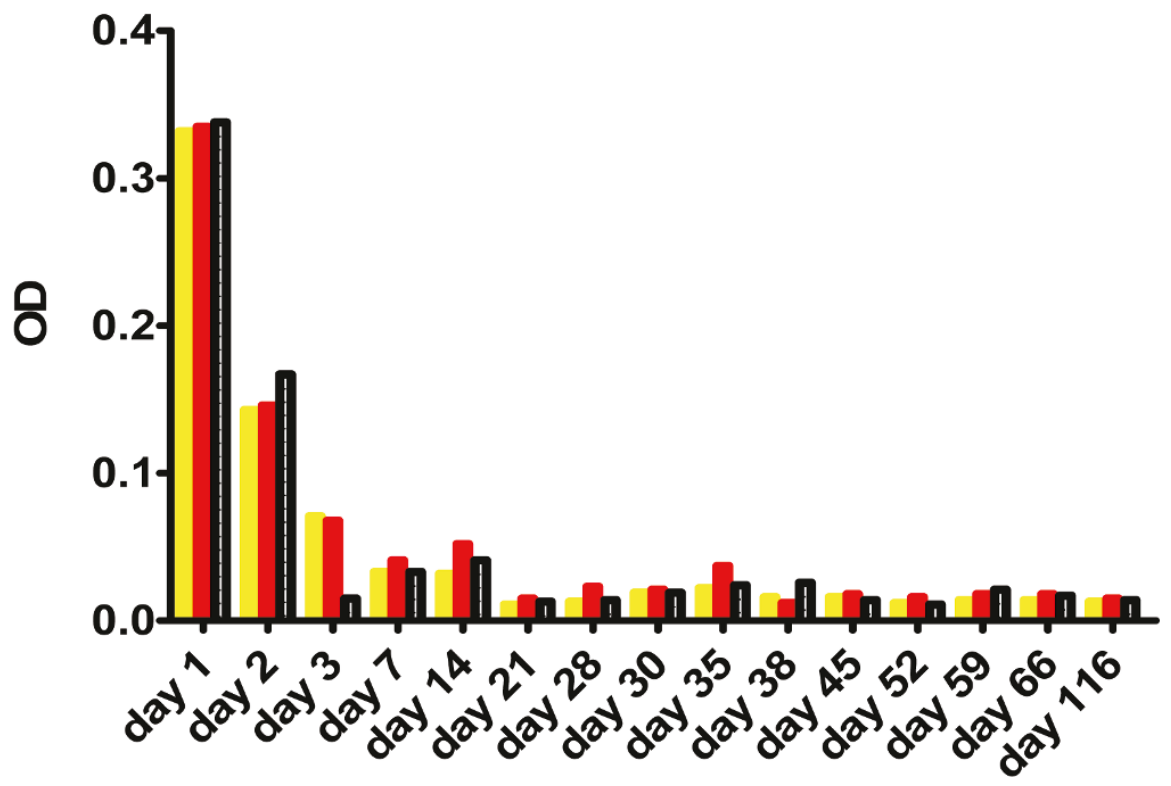

Figure 4 Changes in caspases expression levels in vito.

Clinical correlations

In HCC cases, Fas-RNA and protein expression were significantly associated with the presence of cirrhosis ( $p$ $=0.0027)$ and with poorly differentiated tumors $(\mathrm{p}<$ 0.0001). Bah gene expression was significantly associated with the presence of invasion $(\mathrm{p}=0.05)$, absence of cirrhosis $(\mathrm{p}<0.0001)$ and with well differentiated tumors $(\mathrm{p}<0.0001)$. The expression level of Bcl-2-RNA and protein was significantly associated with poorly differentilted tumors $(\mathrm{p}<0.0001)$ (Table 4$)$.

Table 5 shows that in $\mathrm{CH}$ patients as expression was significantly associated with high hepatitis grade $(\mathrm{p}=$ 0.05), whereas Fast expression was significantly associted with the presence of necrosis as well as with high hepatitis grade and stage $(\mathrm{p}=0.015,0.015$ and 0.006 ; respectively). In contrast, $\mathrm{Bcl}-2$ expression was 


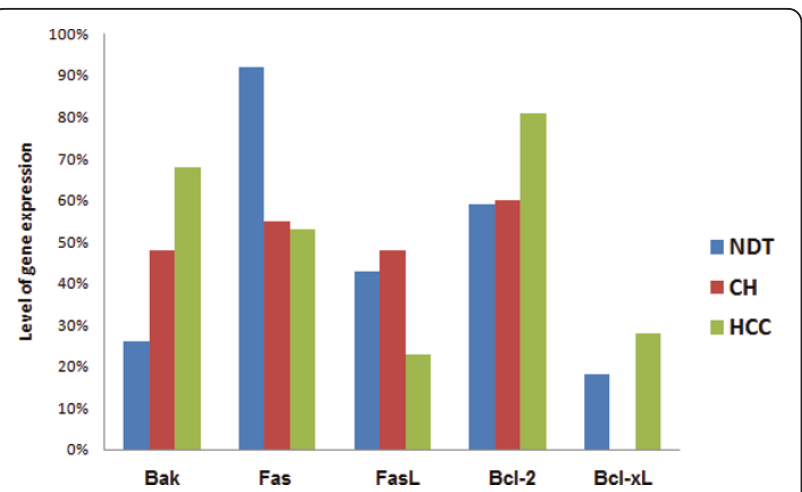

Figure 5 The expression level of the apoptotic genes in the different studied groups. NB: $\mathrm{CH}=$ Chronic hepatitis, $\mathrm{HCC}=$ Hepatocelullar carcinoma, NAT $=$ Normal distant to tumor.

significantly associated with the presence of cirrhosis $(\mathrm{p}<0.0001)$.

\section{Discussion}

An important cause of morbidity and mortality worldwide is the infection by HCV. Progress in understanding $\mathrm{HCV}$ biology has remained challenging due to the lack of an efficient cell culture system for virus growth. Establishment of self-replicating full-length HCV genomic replicons from genotypes in cultured cells has provided an important tool for the study of $\mathrm{HCV}$ replication mechanisms. This study discusses the system for the HepG2 cell line harboring HCV-genotype-4 replication and examines the expression levels of group of genes in clinical samples obtained from $\mathrm{HCC}$ and $\mathrm{CH}$ patients. Other studies have reported another systems for HCV replication, the first with HCV GT1 H77 in immortalized human hepatocytes ( $\mathrm{IHH})$ [34] and the other system of HCV GT2 JFH1 in human hepatoma cell line (Huh7) [35]. Kanda et al. suggested that IHH support $\mathrm{HCV}$ genome replication and virus assembly by examined $\mathrm{HCV}$ core protein-mediated $\mathrm{IHH}$ for growth of HCV [34]. Their study described the generation of cell culture-grown HCV from genotype 1a and discuss the concept of HCV replication and assembly of genotype $1 \mathrm{a}$ in $\mathrm{IHH}$ and speculated that cellular defense mechanisms against $\mathrm{HCV}$ infection are attenuated or compromised in $\mathrm{IHH}$ [34]. It was reported the $\mathrm{HCV}$ production from a HCV-ribozyme construct of genotype 1a (clone H77) in Huh-7 cells with no determination for the virus infectivity [35]. Furthermore, subgenomic replicons of the JFH1 genotype 2a strain cloned from an individual with fulminant hepatitis replicate efficiently in cell culture. The JFH1 genome replicates efficiently and supports secretion of viral particles after transfection into a Huh7, providing a powerful tool for studying the viral life cycle and developing antiviral strategies [35].
Apoptosis has been demonstrated as an important mechanism for viral clearance. In HCV-infected liver, viral persistence is observed despite enhanced hepatocyte apoptosis [5]; however, it is not clear whether this apoptotic effect is due to a direct cytopathic effect of the virus, immunological reactions or a contribution of the molecular mechanisms causing liver damage during $\mathrm{HCV}$ infection $[22,36]$. For understanding the impact of $\mathrm{HCV}$ infection on the apoptotic machinery during disease progression, we studied the expression patterns of Bcl-2, Bcl-xL, Bak, Fas, FasL in HCV- genotype-4 infected HepG2 cell line as well as in human tissue samples obtained from patients with $\mathrm{HCC}$ and $\mathrm{CH}$ as a result of chronic $\mathrm{HCV}$ infection. We also analyzed the expression levels of caspases 3, 8 and 9 in tissue culture medium and in HCV infected cells by a colorimetric assay, and viral replication by both RT-PCR and RealTime PCR for up to 135 days post-infection.

The results of the present study showed that $\mathrm{HCV}$ infection disrupted the process of apoptosis through down regulation of Fas and up-regulation of FasL genes expression. However, in tissue samples a higher expression of Fas and FasL genes were detected in $\mathrm{CH}$ compared to HCC patients, which explains the presence of severe inflammation in chronic HCV infection and its oncogenic potential. In this regard, previous studies demonstrated that enhanced FasL gene expression induces T-cell apoptosis [15], which favors viral persistence and indirectly increases the probability of progression to HCC [36]. In addition, the FasL gene exerts proinflammatory activities via IL- $1 \beta$ secretion that is responsible for neutrophils infiltration [37].

In contrast, other studies [38-40] demonstrated that the ratio of Fas/FasL was significantly lower in HCC than in $\mathrm{CH}$ tissue samples or non tumor hepatic tissues. This was attributed to the fact that tumor cells possess more than one safe guard against Fas mediated apoptosis. First, the reduced expression or loss of certain molecules that are involved in the Fas mediated apoptosis pathway such as FADD (Fas-associated protein with death domain), FLICE (FADD like interleukin-1 $\beta$-coverting enzyme, caspase-8) or FAF (Fas associated factor), or the induction of molecules that would inhibit Fas mediated apoptosis such as FAP (Fas associated phosphatase) [7]. Second, the expression of sFas RNA and FAP-1 may neutralize Fas mediated apoptosis [41] and third, Fas mutation could be expected. Many investigators suggested that one of the possible mechanisms by which HCV core protein inhibits apoptosis is through a direct binding to downstream domain of FADD and cFLIP leads to viral persistence and cells proliferation [5]. Consequently, it is conceivably possible that the observed decreased 


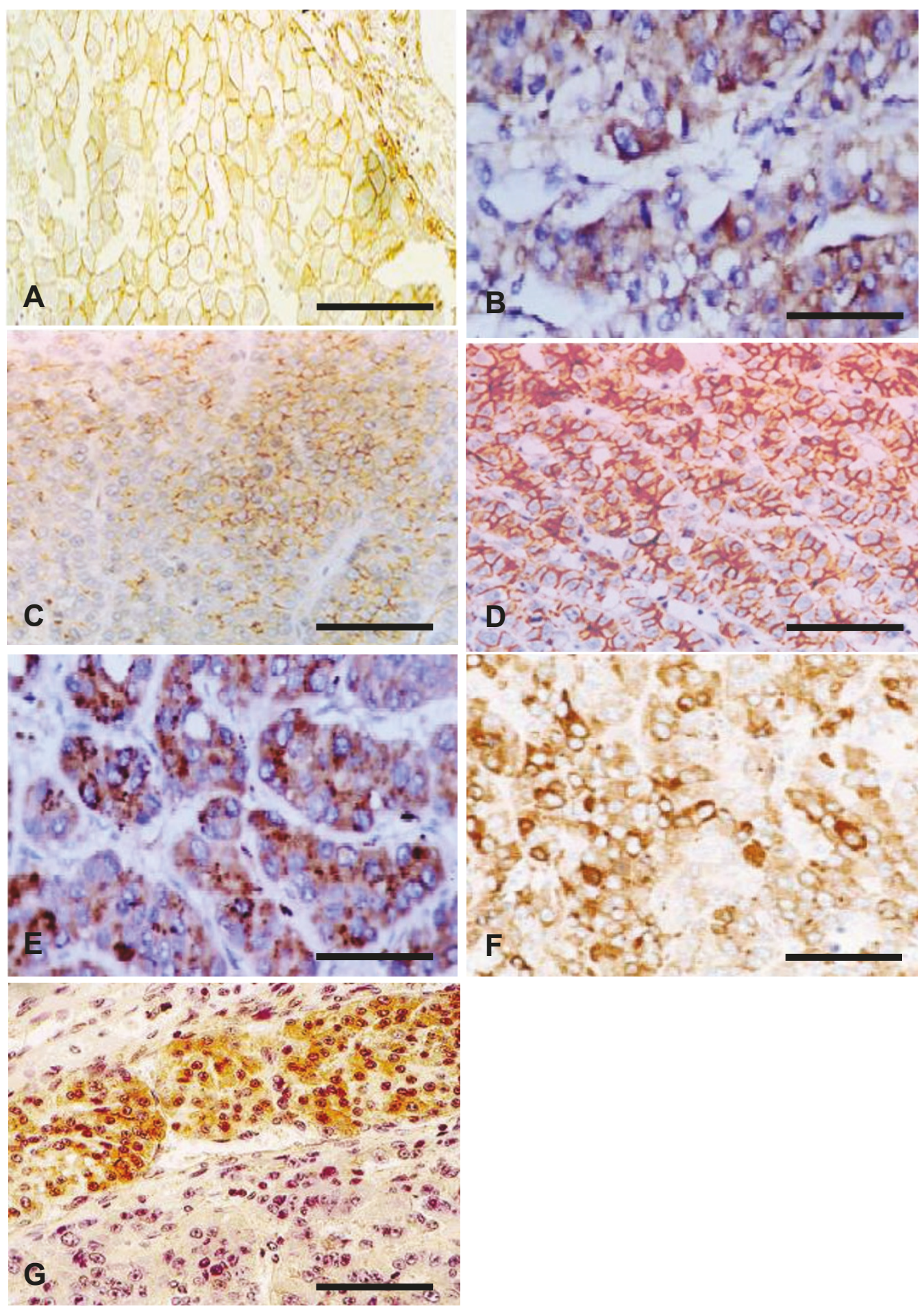

Figure 6 Cases of chronic hepatitis $(\mathrm{CH})$ and hepatocellular carcinoma (HCC). Data from cases of $\mathrm{CH}$ showing (A) high membranous expression of FasL, (B) moderate cytoplasmic expression of FAS and (C) moderate cytoplasmic expression of BCl-2. Cases of HCC showing (D) High membranous expression of FasL, (E) Marked expression of FAS, (F) high expression of BCl-2, and (G) Marked expression of Bcl2 in tumor tissues with loss of expression in adjacent non neoplastic region. Scale bar $=100 \mu \mathrm{m}(\mathrm{A}, \mathrm{C}, \mathrm{D}, \mathrm{G})$ and $200 \mu \mathrm{m}(\mathrm{B}, \mathrm{E}, \mathrm{F})$. 
Table 4 Correlation between gene expression and clinicopathological features in hepatocellular carcinoma cases.

\begin{tabular}{llllll}
\hline Variable & Bak & Fas & FasL & Bcl-2 & Bcl-xL \\
$\mathrm{N}=35$ & $\mathrm{~N}=24$ & $\mathrm{~N}=19$ & $\mathrm{~N}=8$ & $\mathrm{~N}=28$ & $\mathrm{~N}=9$ \\
$(\%)$ & $(\%)$ & $(\%)$ & $(\%)$ & $(\%)$ & $(\%)$ \\
\hline
\end{tabular}

Age (mean \pm SD)

$57 \pm 10.2$

$\leq 55: 16(46)$

$12(75) \quad 7(44) \quad 3(19) \quad 10(63) \quad 5(31)$

$>$ 55: 19 (54)

$12(63)$

$12(63) \# 5(26)$

18 (95) \# $4(21)$

\section{Gender}

M: $22(63)$

F: 13 (37)

Tumor size

$\leq 8:(22)$

$>8:(13)$

Grade

II: 22 (63)

III: 13 (37)

Invasion

Positive: (18)

Negative: (17)

$17(77)$ \# $12(55) \quad 5(23)$

$19(86)$ \# $4(18)$

$7(54)$

7 (54)

$3(23)$

$9(69)$

5 (38) \#

Cirrhosis

Present: 15 (43) $\quad 8(53) \quad 10(67) \# \quad 4(27) \quad 12(80 \%) \quad 3(20)$

Absent: $20(57) \quad 16(80) \# \quad 9(45) \quad 4(20) \quad 16(80 \%) \quad 6(30)$

\# significantly difference $(p<0.005)$

apoptosis relative to cell proliferation of infected hepatocytes could be part of the signaling mechanisms in the pathogenesis of HCC [42].

It has also been reported that the extrinsic (Fas-FasL) pathway plays an important role in liver cell injury directly via $\mathrm{HCV}$ infection or indirectly through immune attack of HCV- infected cells with subsequent recruitment and activation of stellate cells and macrophages, resulting in fibrosis and cirrhosis [43]. Also, I was found that during $\mathrm{HCV}$ infection, $\mathrm{HCV}$-specific $\mathrm{T}$ cells migrate to the liver and recognize viral antigens on the hepatocytes [38]. These immunologically active cells, which are probably induced due to inflammation rather than viral infection, become activated and express FasL that transduces the apoptotic death signal to Fas bearing hepatocytes, resulting in their destruction [38]. Therefore, neither Fas expression nor the degree of liver injury correlates with the intra-hepatic viral load $[15,44]$. In such case, the TNF or the IFN- $\delta$ might be responsible for the up regulation of Fas expression in infected hepatocytes and FasL in lymphocytes [45].

Alternatively, the hepatocytes which are likely type II cells in which direct activation of caspase 8 (extrinsic pathway mechanism) is not sufficient to induce apoptosis amplification by a mitochondrial pathway (intrinsic mechanism) are highly required. Accordingly caspase 8
Table 5 Correlation between gene expression and clinicopathological features in $\mathrm{CH}$ patients

\begin{tabular}{|c|c|c|c|c|}
\hline $\begin{array}{l}\text { Variable } \\
N=34 \\
(\%)\end{array}$ & $\begin{array}{l}\text { Bak } \\
N=16 \\
(\%)\end{array}$ & $\begin{array}{l}\text { Fas } \\
\mathrm{N}=19 \\
(\%)\end{array}$ & $\begin{array}{l}\text { FasL } \\
\mathrm{N}=16 \\
(\%)\end{array}$ & $\begin{array}{l}\mathrm{BCl}-2 \\
\mathrm{~N}=20 \\
(\%)\end{array}$ \\
\hline \multicolumn{5}{|c|}{ Age (mean \pm SD) } \\
\hline \multicolumn{5}{|l|}{$44 \pm 9.8$} \\
\hline$\leq 47: 18(53)$ & $8(44)$ & 13 (72) \# & $8(44)$ & $9(50)$ \\
\hline$>47: 16(47)$ & $8(50)$ & $6(38)$ & $8(50)$ & $11(69)$ \\
\hline \multicolumn{5}{|l|}{ Gender } \\
\hline M: 31 (91) & $13(41)$ & $17(55)$ & $15(48)$ & $18(58)$ \\
\hline F: 3 (8) & $3(100) \#$ & $2(67) \#$ & $1(33)$ & $2(66)$ \\
\hline \multicolumn{5}{|l|}{ Steatosis } \\
\hline Absent: (10) & $3(30)$ & $3(30)$ & $2(20)$ & $4(40)$ \\
\hline Minimal: (14) & $7(50)$ & $9(64)$ & $4(29)$ & $10(71)$ \\
\hline Moderate: (7) & $4(57)$ & $5(71)$ & $7(100)$ & $5(71)$ \\
\hline Marked: (3) & $2(67)$ & $2(67)$ & $3(100)$ & $1(33)$ \\
\hline \multicolumn{5}{|l|}{ Necrosis } \\
\hline Absent: (26) & $12(46)$ & $13(50)$ & $9(35)$ & $16(62)$ \\
\hline Minimal: (8) & $4(50)$ & $6(75)$ & 7 (88) \# & $4(50)$ \\
\hline \multicolumn{5}{|l|}{$\begin{array}{l}\text { Necro- } \\
\text { inflammation }\end{array}$} \\
\hline Absent: (10) & $4(40)$ & $5(50)$ & $0(0)$ & $3(30)$ \\
\hline Minimal: (15) & $8(53)$ & $9(60)$ & $8(53)$ & $11(73)$ \\
\hline Moderate: (9) & $4(44)$ & $5(56)$ & $8(89)$ & $6(67)$ \\
\hline \multicolumn{5}{|l|}{ Cirrhosis } \\
\hline Present:12 (35) & $6(50)$ & $6(50)$ & $6(50)$ & $9(75) \#$ \\
\hline Absent: 22 (65) & $10(45 \%)$ & $13(59)$ & $10(45)$ & $11(50)$ \\
\hline \multicolumn{5}{|l|}{ Hepatitis grade } \\
\hline | \& II: (26) & $11(42)$ & $12(46)$ & $9(35)$ & $15(58)$ \\
\hline III\&IV: (8) & $5(63)$ & 7 (88) \# & $7(88) \#$ & $5(63)$ \\
\hline \multicolumn{5}{|l|}{ Hepatitis stage } \\
\hline I \&ll: (25) & $12(48)$ & $13(52)$ & $8(32)$ & $16(64)$ \\
\hline III \&IV: (9) & $4(44)$ & $6(67)$ & 8 (89) \# & $4(44)$ \\
\hline
\end{tabular}

$\mathrm{BCl}-\mathrm{xL}$ was not expressed in any of the studied $\mathrm{CH}$ cases. \# significantly difference $(p<0.005)$.

activation causes the proapoptotic cleavage of Bid, which induces cytochrome $c$ release from the mitochondria, which subsequently binds to Apaf- 1 and procaspase 9 forming apoptosome complex [29]. In the present study, we assessed the activation of caspases 8 , and 9, which represent both death receptor-mediated and the mitochondrial apoptosis pathway and caspase 3 which is an executioner caspase. Our data showed a positive correlation between Fas mediated apoptosis and caspases activation. In HCV infected cells, we observed a loss of caspases after 4 weeks post HCV infection. Some studies provided evidence that monitoring of caspases activation might be helpful as a diagnostic tool to detect the degree of $\mathrm{HCV}$ mediated inflammatory liver damage and to evaluate efficacy of HCV therapy [36,37]. However, it was reported that the extent of caspase activation correlates with the grade of the disease but not 
with surrogate markers, such as serum transaminases or viral load [36]. This observation indicates that caspase activation is not directly related to $\mathrm{HCV}$ mediated damage and suggests the involvement of $\mathrm{HCV}$ mediated immune response with Fas triggered hepatocyte apoptosis giving rise to several amplification loops [36]. Similar findings were reported by others, who indicated in their study that the core protein could stimulate caspaseindependent apoptosis at later stages of the disease giving relevance to the release of $\mathrm{HCV}$ particles from the host cells and to viral spread [46].

It has been shown that some HCCs are resistant to Fas-mediated apoptosis directly through the expression of $\mathrm{HCV}$ proteins or indirectly through up-regulation of Bcl-2 family members [36]. Our data showed that both $\mathrm{Bcl}-2$ and Bcl-xL RNA expression were significantly higher in $\mathrm{HCC}$ than in $\mathrm{CH}$ and NDT indicating late involvement of those genes in the cascade of HCV-associated hepatocarcinogenesis. We were also able to detect Bcl-2 gene expression in HepG2 cells starting from day 1 post-infection until the end of the experiment, whereas the expression of Bcl-xL was not visible until day 28 when it started to be expressed and its expression was closely associated with the presence of $\mathrm{HCV}$ in tumor cells (Table 3 ) suggesting that Bcl-2 is tumor related whereas $\mathrm{Bcl}-\mathrm{xL}$ is a viral related. In this context, Bcl-2 was linked to inhibition of apoptosis via interfering with either the recruitment of procaspase 8 to Fas receptors [47] or by preventing the release of cytochrome $\mathrm{C}$ [5]. It has also been shown that the HCV core protein inhibits apoptosis at the mitochondrial level through augmentation of $\mathrm{Bcl}-\mathrm{xL}$ expression with consequent inhibition of caspase 3 activation [16]. The $\mathrm{HCV}$ core protein could induce apoptosis in the Fas death way although this is achieved through the activation of Bax and Bak, both are important mediators of p53 mitochondrial function $[5,36]$. Our results showed an increase in Bak-RNA expression at an early stage of $\mathrm{HCV}$ infection of HepG2 cells, which is also observed in tissue samples obtained from both $\mathrm{CH}$ and $\mathrm{HCC}$ patients compared to NDT samples. Our results provided enough evidence that the Bak gene can induce apoptosis in HCC cells even in the presence of high levels of the anti-apoptotic Bcl-2 gene family members, which is in agreement with the findings of others [48].

The results of gene expression in tissue samples show a significant correlation between Fas expression in HCC cases and the presence of cirrhosis or poorly differentiated tumors. We observed that FasL expression was significantly associated in $\mathrm{CH}$ patients with the grade of inflammation and the stage of fibrosis as well as with the presence of severe necro-inflammatory changes. Based on these results we conclude that aberrant expression of Fas and FasL in HCV-infected patients could be considered a marker for increased disease severity with a higher possibility of progression into cirrhosis and/or HCC. Similar results were also reported by others [49], who indicated that FasL may contribute to malignant transformation of hepatocyte as it was significantly expressed in the peri-cancerous lobules and cirrhotic nodules [42]. Similarly, Bcl-2 expression was significantly associated with poorly-differentiated tumors as well as with the presence of cirrhosis in $\mathrm{CH}$ patients. Similar findings were reported previously by some of us [32]. In this study, Bak expression was significantly associated with absence of cirrhosis and well-differentiated tumors, thus Bak gene could be considered a good prognostic marker.

The impact of HCV infection on modulating apoptotic machinery pathway(s) differs during the course of infection, as the disease progresses apoptosis is inhibited leading to cell immortalization and HCC development. $\mathrm{HCV}$ infection could exert a direct effect on hepatocytes by inducing Fas-FasL pathway with subsequent inactivation of caspases or indirectly by immune attack on hepatocytes resulting in $\mathrm{HCV}$ mediated liver injury, viral persistence and cirrhosis in $\mathrm{CH}$ patients with an increasing possibility of hepatocarcinogenesis especially with increasing proliferation rate and acquisition of genetic damage.

Alternatively, HCV infection could induce apoptosis at the early phase of infection followed by modulation of apoptosis by disturbing Fas/FasL. This in turn would cause an inactivation of caspases 3,8 , and 9, up-regulation of Bcl-2 family members, impairment in Bak gene expression and increasing the expression of FasL leading to inhibition of apoptosis in HCV infected patients. This signaling cascade favors cell survival with persistence of $\mathrm{HCV}$ infection and enhances the possibility of HCC development. A combination of these effects initiates a circle of hepatocyte damage and repair, which is the hallmark of HCV infection that might progress to HCC. Our study could provide an insight for understanding apoptosis and developing molecular target therapies that could inhibit viral persistence and HCC development. Further studies are still required to clarify the interaction between other $\mathrm{HCV}$ proteins in the apoptotic machinery system and the possible involvement of other apoptotic pathways in $\mathrm{HCV}$ associated HCC development.

\section{Conclusions}

Chronic HCV infection modulates the apoptotic machinery differently during the course of infection, where the virus induces apoptosis early in the course of infection, and as the disease progresses apoptosis is modulated. This study could open a new opportunity for understanding the various signallings of apoptosis 
and in the developing a targeted therapy to inhibit viral persistence and HCC development. Nevertheless, further studies are mandatory to clarify the interaction between other HCV proteins in the apoptotic machinery system and the possible involvement of other apoptotic pathways in $\mathrm{HCV}$ associated $\mathrm{HCC}$ development.

\section{Acknowledgements}

Grant support from the National Cancer Institute Grant Office and Research Center, Cairo University, Egypt.

\section{Author details}

${ }^{1}$ Virology and Immunology Unit, Cancer Biology Department, National Cancer Institute, Cairo University, Egypt. ${ }^{2}$ Pathology Department, National Cancer Institute, Cairo University, Egypt. ${ }^{3}$ Clinical Pathology Department, National Cancer Institute, Cairo University, Egypt. ${ }^{4}$ Biostatistic \& Epidemiology Department, National Cancer Institute, Cairo University, Egypt. ${ }^{5}$ Tropical Medicine Department, Ain Shams University, Egypt. ${ }^{6}$ Center for Integrated Biotechnology, Washington State University, Pullman, WA, USA.

\section{Authors' contributions}

ARNZ made substantial contributions to conception and design, carried out the tissue culture and molecular genetic studies and gave the final approval of the version to be published. AAB carried out pathological and the immunohistochemistry studies. MMH carried out the tissue culture and molecular genetic studies, participated in the design of the study and performed the statistical analysis. ZKH participated in the molecular studies and participated in the statistical analysis, interpretation of data and drafted the manuscript. MK participated in pathological studies. SAL participated in drafting the manuscript. GMS participated in the statistical analysis. AREZ provided all clinical samples and data. SSD participated in drafting the manuscript and revised the manuscript critically for important intellectual content. All authors read and approved the final manuscript.

\section{Competing interests}

The authors declare that they have no competing interests.

Received: 14 August 2010 Accepted: 23 July 2011

Published: 23 July 2011

\section{References}

1. Shepard CW, Finelli L, Alter MJ: Global epidemiology of hepatitis C virus infection. Lancet Infect Dis 2005, 5(9):558-567.

2. Eassa S, Eissa M, Sharaf SM, Ibrahim MH, Hassanein OM: Prevalence of hepatitis $C$ virus infection and evaluation of a health education program in el-ghar village in zagazig, egypt. J Egypt Public Health Assoc 2007, 82(56):379-404.

3. AbdulQawi K, Youssef A, Metwally MA, Ragih I, AbdulHamid M, Shaheen A: Prospective study of prevalence and risk factors for hepatitis $C$ in pregnant Egyptian women and its transmission to their infants. Croat Med J 2010, 51(3):219-228.

4. El-Karaksy HM, Anwar G, Esmat G, Mansour S, Sabry M, Helmy H, ElHennawy A, Fouad $\mathrm{H}$ : Prevalence of hepatic abnormalities in a cohort of Egyptian children with type 1 diabetes mellitus. Pediatr Diabetes 2009, 1(7):462-70.

5. Fischer $R$, Baumert $T$, Blum HE: Hepatitis $C$ virus infection and apoptosis. World J Gastroenterol 2007, 13(36):4865-4872.

6. Mankouri J, Dallas ML, Hughes ME, Griffin SD, Macdonald A, Peers C, Harris M: Suppression of a pro-apoptotic $\mathrm{K}+$ channel as a mechanism for hepatitis C virus persistence. Proc Natl Acad Sci USA 2009, 106(37):15903-15908.

7. Shin EC, Shin JS, Park JH, Kim JJ, Kim H, Kim SJ: Expression of Fas-related genes in human hepatocellular carcinomas. Cancer Lett 1998, 134(2):155-162.

8. Pitot HC: The molecular biology of carcinogenesis. Cancer 1993, 72(3 Suppl):962-970.

9. Kumar S: Caspase function in programmed cell death. Cell Death Differ 2007, 14(1):32-43.
10. Machida K, Tsukamoto H, Liu JC, Han YP, Govindarajan S, Lai MM, Akira S, $\mathrm{Ou} J \mathrm{H}$ : c-Jun mediates hepatitis $\mathrm{C}$ virus hepatocarcinogenesis through signal transducer and activator of transcription 3 and nitric oxidedependent impairment of oxidative DNA repair. Hepatology 2010, 52(2):480-492.

11. Panasiuk A, Parfieniuk A, Zak J, Flisiak R: Association among Fas expression in leucocytes, serum Fas and Fas-ligand concentrations and hepatic inflammation and fibrosis in chronic hepatitis C. Liver Int 2010, 30(3):472-478

12. Basu A, Saito K, Meyer K, Ray RB, Friedman SL, Chang YH, Ray R: Stellate cell apoptosis by a soluble mediator from immortalized human hepatocytes. Apoptosis 2006, 11(8):1391-1400.

13. Rokhlin OW, Bishop GA, Hostager BS, Waldschmidt TJ, Sidorenko SP, Pavloff N, Kiefer MC, Umansky SR, Glover RA, Cohen MB: Fas-mediated apoptosis in human prostatic carcinoma cell lines. Cancer Res 1997, 57(9):1758-1768

14. Brenner C, Grimm S: The permeability transition pore complex in cancer cell death. Oncogene 2006, 25(34):4744-4756.

15. Calabrese F, Pontisso P, Pettenazzo E, Benvegnu L, Vario A, Chemello L, Alberti A, Valente M: Liver cell apoptosis in chronic hepatitis C correlates with histological but not biochemical activity or serum HCV-RNA levels. Hepatology 2000, 31(5):1153-1159.

16. Otsuka M, Kato N, Taniguchi H, Yoshida H, Goto T, Shiratori Y, Omata M: Hepatitis $C$ virus core protein inhibits apoptosis via enhanced $\mathrm{BCl}-\mathrm{xL}$ expression. Virology 2002, 296(1):84-93.

17. Machida K, Tsukiyama-Kohara K, Seike E, Tone S, Shibasaki F, Shimizu M, Takahashi H, Hayashi Y, Funata N, Taya C, Yonekawa H, Kohara M: Inhibition of cytochrome $\mathrm{c}$ release in Fas-mediated signaling pathway in transgenic mice induced to express hepatitis $C$ viral proteins. J Biol Chem 2001, 276(15):12140-12146.

18. Hahn CS, Cho YG, Kang BS, Lester IM, Hahn YS: The HCV core protein acts as a positive regulator of fas-mediated apoptosis in a human lymphoblastoid T cell line. Virology 2000, 276(1):127-137.

19. Ray RB, Meyer K, Steele R, Shrivastava A, Aggarwal BB, Ray R: Inhibition of tumor necrosis factor (TNF-alpha)-mediated apoptosis by hepatitis $C$ virus core protein. J Biol Chem 1998, 273(4):2256-2259.

20. Ruggieri A, Harada T, Matsuura Y, Miyamura T: Sensitization to Fasmediated apoptosis by hepatitis C virus core protein. Virology 1997, 229(1):68-76.

21. Dumoulin FL, vsn dem Bussche A, Sohne J, Sauerbruch T, Spengler U: Hepatitis $C$ virus core protein does not inhibit apoptosis in human hepatoma cells. Eur J Clin Invest 1999, 29(11):940-946.

22. Kalkeri G, Khalap N, Garry RF, Fermin CD, Dash S: Hepatitis C virus protein expression induces apoptosis in HepG2 cells. Virology 2001, 282(1):26-37.

23. Ishak K, Baptista A, Bianchi L, Callea F, De Groote J, Gudat F, Denk H, Desmet V, Korb G, MacSween RN, Phillipsk MJ, Portmannl BG, Poulsenm H, Scheuer PJ, Schmidn M, Thalero H: Histological grading and staging of chronic hepatitis. J Hepatol 1995, 22(6):696-699.

24. Hamilton SRAL: World Health Organization classification of tumours. Pathology and genetics of tumours of the digestive system. IARC Press, Lyon; 2000, 157-202.

25. Seipp S, Mueller HM, Pfaff E, Stremmel W, Theilmann L, Goeser T: Establishment of persistent hepatitis $C$ virus infection and replication in vitro. J Gen Virol 1997, 78(Pt 10):2467-2476.

26. El-Awady MK, Tabll AA, el-Abd YS, Bahgat MM, Shoeb HA, Youssef SS, Bader el-Din NG, Redwan el RM, el-Demellawy M, Omran MH, et al: HepG2 cells support viral replication and gene expression of hepatitis $C$ virus genotype 4 in vitro. World J Gastroenterol 2006, 12(30):4836-4842.

27. Zekri AR, El-Din HM, Bahnassy AA, Khaled MM, Omar A, Fouad I, ElHefnewi M, Thakeb F, El-Awady M: Genetic distance and heterogenecity between quasispecies is a critical predictor to IFN response in Egyptian patients with HCV genotype-4. Virol J 2007, 4:16.

28. Zekri AR, Bahnassy AA, El-Din HM, Salama HM: Consensus siRNA for inhibition of HCV genotype-4 replication. Virol J 2009, 6:13.

29. Joyce MA, Walters KA, Lamb SE, Yeh MM, Zhu LF, Kneteman N, Doyle JS, Katze MG, Tyrrell DL: HCV induces oxidative and ER stress, and sensitizes infected cells to apoptosis in SCID/Alb-uPA mice. PLoS Pathog 2009, 5(2): e1000291.

30. He Y, Ferencik S, Luo D: [Detection of replicative form of HCV RNA in peripheral blood leukocytes and its clinical significance]. Zhonghua Nei Ke Za Zhi 1995, 34(7):459-462 
31. Boom R, Sol CJ, Heijtink R, Wertheim-van Dillen PM, van der Noordaa J: Rapid purification of hepatitis B virus DNA from serum. J Clin Microbiol 1991, 29(9):1804-1811.

32. Zekri AR, Bahnassy AA, Abdel-Wahab SA, Khafagy MM, Loutfy SA, Radwan $\mathrm{H}$, Shaarawy SM: Expression of pro- and anti-inflammatory cytokines in relation to apoptotic genes in Egyptian liver disease patients associated with HCV-genotype-4. J Gastroenterol Hepatol 2009, 24(3):416-428.

33. Khaled HM, Bahnassy AA, Raafat AA, Zekri AR, Madboul MS, Mokhtar NM: Clinical significance of altered nm23-H1, EGFR, RB and p53 expression in bilharzial bladder cancer. BMC Cancer 2009, 9:32.

34. Kanda T, Basu A, Steele R, Wakita T, Ryerse JS, Ray R, Ray RB: Generation of infectious hepatitis $C$ virus in immortalized human hepatocytes. J Virol 2006, 80(9):4633-4639.

35. Wakita T, Pietschmann T, Kato T, Date T, Miyamoto M, Zhao Z, Murthy K, Habermann A, Krausslich HG, Mizokami M, Bartenschlager R, Liang TJ: Production of infectious hepatitis $C$ virus in tissue culture from a cloned viral genome. Nat Med 2005, 11(7):791-796.

36. Bantel $\mathrm{H}$, Schulze-Osthoff $\mathrm{K}$ : Apoptosis in hepatitis $\mathrm{C}$ virus infection. Cell Death Differ 2003, 10(Suppl 1):S48-58.

37. Bantel H, Lugering A, Poremba C, Lugering N, Held J, Domschke W, Schulze-Osthoff K: Caspase activation correlates with the degree of inflammatory liver injury in chronic hepatitis $C$ virus infection. Hepatology 2001, 34(4 Pt 1):758-767.

38. Roskams T, Libbrecht L, Van Damme B, Desmet V: Fas and Fas ligand: strong co-expression in human hepatocytes surrounding hepatocellular carcinoma; can cancer induce suicide in peritumoural cells? J Pathol 2000, 191(2):150-153.

39. Nagao M, Nakajima $Y$, Hisanaga M, Kayagaki N, Kanehiro H, Aomatsu $Y$, Ko S, Yagita H, Yamada T, Okumura K, Nakano H: The alteration of Fas receptor and ligand system in hepatocellular carcinomas: how do hepatoma cells escape from the host immune surveillance in vivo? Hepatology 1999, 30(2):413-421.

40. Kubo K, Matsuzaki Y, Okazaki M, Kato A, Kobayashi N, Okita K: The Fas system is not significantly involved in apoptosis in human hepatocellular carcinoma. Liver 1998, 18(2):117-123.

41. Lee SH, Shin MS, Lee HS, Bae JH, Lee HK, Kim HS, Kim SY, Jang JJ, Joo M, Kang YK, Park WS, Park JY, Oh RR, Han SY, Lee JH, Kim SH, Lee JY, Yoo NJ: Expression of Fas and Fas-related molecules in human hepatocellular carcinoma. Hum Pathol 2001, 32(3):250-256.

42. Nada O, Abdel-Hamid M, Ismail A, El Shabrawy L, Sidhom KF, El Badawy NM, Ghazal FA, El Daly M, El Kafrawy S, Esmat G, Loffredo CA: The role of the tumor necrosis factor (TNF)-Fas $L$ and HCV in the development of hepatocellular carcinoma. J Clin Virol 2005, 34(2):140-146.

43. Feldstein AE, Canbay A, Angulo P, Taniai M, Burgart LJ, Lindor KD, Gores GJ: Hepatocyte apoptosis and fas expression are prominent features of human nonalcoholic steatohepatitis. Gastroenterology 2003, 125(2):437-443.

44. McGuinness PH, Bishop GA, Painter DM, Chan R, McCaughan GW: Intrahepatic hepatitis C RNA levels do not correlate with degree of liver injury in patients with chronic hepatitis C. Hepatology 1996, 23(4):676-687.

45. Muschen M, Warskulat U, Peters-Regehr T, Bode JG, Kubitz R, Haussinger D: Involvement of CD95 (Apo-1/Fas) ligand expressed by rat Kupffer cells in hepatic immunoregulation. Gastroenterology 1999, 116(3):666-677.

46. Berg CP, Schlosser SF, Neukirchen DK, Papadakis C, Gregor M, Wesselborg S, Stein GM: Hepatitis $C$ virus core protein induces apoptosis-like caspase independent cell death. Virol J 2009, 6:213.

47. Kawahara A, Kobayashi T, Nagata S: Inhibition of Fas-induced apoptosis by Bcl-2. Oncogene 1998, 17(20):2549-2554.

48. Pataer A, Fang B, Yu R, Kagawa S, Hunt KK, McDonnell TJ, Roth JA, Swisher SG: Adenoviral Bak overexpression mediates caspase-dependent tumor killing. Cancer Res 2000, 60(4):788-792.

49. Hirashima N, Matsumoto Y, Ohono T, Kimura Y, Hasegawa I, Ueda R: Hepatic Fas protein expression might be a predictive factor for hepatocellular carcinoma development in patients with chronic hepatitis C undergoing interferon therapy. J Clin Gastroenterol 2002, 34(3):263-267.

doi:10.1186/1476-5926-10-4

Cite this article as: Zekri et al:: Characterization of chronic HCV infection-induced apoptosis. Comparative Hepatology 2011 10:4.

\section{Submit your next manuscript to BioMed Central and take full advantage of:}

- Convenient online submission

- Thorough peer review

- No space constraints or color figure charges

- Immediate publication on acceptance

- Inclusion in PubMed, CAS, Scopus and Google Scholar

- Research which is freely available for redistribution 